\title{
PENGARUH PELATIHAN PIJAT BAYI TERHADAP PERILAKU IBU DI WILAYAH KELURAHAN PLESUNGAN
}

\author{
Ari Pebru Nurlaily ${ }^{1}$, Meri Oktariani ${ }^{2}$ \\ STIKes Kusuma Husada Surakarta \\ aryuko_laily@yahoo.com
}

\begin{abstract}
ABSTRAK
Pijat bayi yang dilakukan oleh orang tua memberikan manfaat, dapat menumbuhkan rasa percaya diri orang tua, meningkatkan pertumbuhan dan perkembangan bayi. Dampak positif yang ditimbulkan oleh pijat bayi umumnya bayi yang mendapat pijatan secara teratur akan lebih rileks dan tenang. Berdasarkan fenomena yang ada bahwa sebagian besar ibu tidak berani melakukan pijat bayi secara mandiri dikarenakan banyak hal terutama belum paham tentang prosedur pijat bayi dan manfaatnya. Tujuan dari penelitian ini adalah untuk mengetahui pengaruh pelatihan pijat bayi terhadap tingkat perilaku ibu di Wilayah Kelurahan Plesungan. Penelitian ini merupakan penelitian pre eksperiment dengan desain one group pretes-post test design. Sampel sebanyak 20 responden menggunakan total sampling. Tehnik pengumpulan data data dilakukan dengan checklist dan lembar observasi sebelum dan setelah diberikan pelatihan. Data yang terkumpul dianalisis dengan uji Wilkoxon $\mathrm{p}$ value $=0,000$ $(\mathrm{p}<0,05)$, dapat disimpulkan adanya pengaruh pelatihan pijat bayi terhadap perilaku ibu di wilayah kelurahan Plesungan.
\end{abstract}

Kata Kunci: Pijat Bayi, Pelatihan, Perilaku

\begin{abstract}
The baby massage which is performed by parents give some benefits such as; growing the parents' confidence, improving the growth and development. Generally, the positive effect of regular baby massage will give more relax and calm. Based on the phenomenon, most of mothers do not have courage to conduct baby massage independently. It is caused by a problem that mothers do not understand the procedure of baby massage training and the benefits. The purpose of this research is to identify the effect of baby massage training on the level of mother's behavior in Plesungan Area. This research is pre-experiment with one group pre-post test design. The samples were 20 respondents who used total sampling. The data collection technique were performed by checklist and questionaire sheet in pre and post training. The collected data were analyzed by Wilkoxon test $p=$ $0,000(p<0,05)$. It can be concluded that there is an effect of baby massage training on mother behavior in Plesungan Area.
\end{abstract}

Keywords: Baby Massage, Training, Behavior 


\section{PENDAHULUAN}

Sentuhan merupakan interaksi awal manusia, ketika lahir bayi merespon rangsangan fisik yang dirasakan oleh kulit sebagai indera perasa yang aktif (Subakti \& Rizky, 2008). Pijat bayi yang dilakukan secara teratur dengan teknik yang benar, bisa menjadi terapi untuk mendapatkan banyak manfaat bagi bayi.

Pijat bayi yang dilakukan oleh orang tua memberikan manfaat, dapat menumbuhkan rasa percaya diri orang tua, meningkatkan pertumbuhan dan perkembangan bayi, mempersingkat masa tinggal perawatan bayi di rumah sakit (setelah melahirkan) menjadi tiga sampai enam hari lebih awal, meningkatkan berat badan sampai $47 \%$, mengurangi masalah tidur bayi, menurunkan hormon stress bayi, meningkatkan kekebalan tubuh bayi, mengubah gelombang otak secara positif, mengurangi kembung (sakit perut), membuat tidur lebih lelap, mengurangi rasa sakit, merangsang fungsi pencernaan serta pembuangan, memperbaiki sirkulasi darah dan pernafasan, memberikan relaksasi, mengembangkan kepekaan dan membangun percaya diri (Roesli, 2010).

Fakta yang ada di masyarakat, meskipun pijat bayi memiliki manfaat yang besar bagi bayi dan ibu jika dilakukan secara mandiri. Namun, ibu saat ini belum mau memijat bayinya sendiri dengan alasan takut salah pijat dan merasa tidak puas jika dilakukan sendiri. Penyebab dalam hal ini adalah kurang pengetahuan ibu tentang pentingnya pelaksanaan pijat bayi secara mandiri sehingga menimbulkan perilaku negatif terhadap stimulasi pemijatan bayi secara mandiri (Mauliddina, 2011).

Fenomena yang ada, meskipun ibu balita telah mengtahui manfaat pijat bayi begitu besar, namun saat ini ibu belum mau memijat bayinya secara mandiri dengan alasan takut jika salah pijat dan kurang puas jika dipijat sendiri oleh ibu dan lebih suka memijatkan ke dukun bayi. Sebagai bahan pertimbangan, pengetahuan sangat diperlukan dalam melakukan pijat bayi yang benar. Berdasarkan wawancara sebagian besar ibu tidak melakukan pijat bayi secara mandiri. Untuk itu perlu adanya analisis pelatihan tentang pijat bayi terhadap perilaku ibu mengenai pijat bayi.

\section{METODE}

Penelitian ini merupakan penelitian pre eksperiment dengan desain one group pretespost test design. Sampel sebanyak 20 responden menggunakan total sampling. Tehnik pengumpulan data data dilakukan dengan checklist dan lembar observasi sebelum dan setelah diberikan pelatihan.

HASIL DAN PEMBAHASAN

Tabel 1. Distribusi Frekuensi Perilaku Responden Sebelum Diberikan Pelatihan Pijat Bayi

\begin{tabular}{lcc}
\hline Kriteria & Jumlah & $\begin{array}{c}\text { Persentase } \\
(\mathbf{\%})\end{array}$ \\
\hline Kurang & 20 & 100,0 \\
\hline Cukup & 0 & 0 \\
\hline Baik & 0 & 0 \\
\hline Total & 20 & 100,0 \\
\hline
\end{tabular}

Sebelum diberikan pelatihan pijat bayi (pre test), didapatkan data perilaku ibu dikategorikan kurang dalam melakukan pijat bayi, akibatnya ibu belum tahu bagaimana cara melakukan pijat bayi yang benar dan belum melakukan secara mandiri dengan alasan yang beragam, diantaranya tidak berani melakukan sendiri, takut salah urut, tidak ada waktu. Dampak tidak diterapkannya pijat bayi secara mandiri akan menyebabkan pertumbuhan dan perkembangan bayi yang kurang optimal.

Tabel 2. Distribusi Frekuensi Perilaku Responden Setelah Diberikan Pelatihan Pijat Bayi

\begin{tabular}{lcc}
\hline Kriteria & Jumlah & $\begin{array}{c}\text { Persentase } \\
(\boldsymbol{\%})\end{array}$ \\
\hline Kurang & 3 & 15,0 \\
\hline Cukup & 13 & 65,0 \\
\hline Baik & 4 & 20,0 \\
\hline Total & 20 & 100,0 \\
\hline
\end{tabular}

Tabel 2 menunjukkan bahwa kriteria kurang sebanyak 15\%, kriteria baik 20\% dan paling besar adalah persentase dari kriteria cukup yaitu $65 \%$.

Data post test pemberian pelatihan didapatkan hasil adanya peningkatan yang signifikan yakni $65 \%$ dengan kategori cukup dan $20 \%$ dengan kategori baik. Hal ini berarti ada peningkatan yang cukup baik dalam perilaku ibu memijat bayinya secara mandiri, sebagian besar ibu melakukan pemijatan 
sesuai prosedur dan memperhatikan hal-hal yang dianjurkan dan tidak dianjurkan selama pelaksanaan pemijatan.



Hipotesis yang menyatakan bahwa adanya pengaruh pelatihan pijat bayi terhadap perilaku ibu di wilayah kelurahan Plesungan dalam penelitian ini terbukti. Hal ini terbukti dengan hasil uji wilcoxon diperoleh hasil nilai $\mathrm{Z}-3.287^{\mathrm{a}}$ dan $\mathrm{p}$-value 0,000 menunjukkan hipotesis diterima. Terlihat jelas selisih kedua data pre-test dan post-test bermakna. Hal ini berarti dengan adanya pelatihan pijat bayi sangat membantu ibu dalam meningkatkan perilakunya dalam melakukan pemijatan bayi secara mandiri.

Menurut Roesli (2010), pijat bayi adalah terapi sentuhan paling tua dan sebuah seni perawatan kesehatan serta pengobatan yang telah dipraktekkan sejak berabad-abad silam, yakni dengan mengurut bagian tubuh untuk melemaskan otot-otot tubuh sehingga peredaran darah lancar yang dilakukan pada seluruh tubuh bayi. Hal ini sesuai dengan penelitian pengaruh pelatihan pijat bayi terhadap perilaku ibu di Wilayah Kelurahan Plesungan, karena terapi sentuh terutama pijat memberikan manfaat sangatlah besar, terutama manfaat untuk rumbuh kembang anak secara fisik dan paikologis (emosional). Selain itu, manfaat pijat bayi diantaranya adalah memberikan rasa aman dan nyaman pada bayi, dapat meningkatkan berat badfan bayi, meningkatkan daya tahan tubuh bayi, mmembuat bayi tidur lelap, dan meningkatkan tonus nervus vagus yang menyebabkan bayi menjadi lapar sehingga bayi akan lebih sering menyusu.

Pelatihan adalah proses mengajarkan peserta, keterampilan dasar yang mereka butuhkan untuk menunjang peningkatan pengetahuan dan keterampilan. Sehingga masyarakat tidak saja sadar, tahu dan mengerti, namun juga mau dan mampu melakukan anjuran yang baik untuk menunjang kesehatan. Dari penelitian dan pengalaman terbukti bahwa perilaku yang didasari oleh pengetahuan akan lebih awet dari pada perilaku yang tidak ada dasarnya (Notoadmodjo, 2007).

Faktor yang mempengaruhi terjadinya perubahan perilaku juga didukung oleh metode yang digunakan. Pada penelitian ini peneliti memberikan pelatihan pijat bayi dengan metode ceamah, demonstrasi tehnik pijat bayi serta pemberian materi berupa leaflet sehingga ibu dapat mepelajari. Sejalan dengan teori dari Notoadmodjo (2007) bahwa dengan menggunakan alat bantu seperti metode tersebut memberikan manfaat pada responden penelitian, diantaranya menimbulkan minat sasaran pelatihan, mencapai sasaran yang lebih banyak, membantu mengatasi banyak hambatan dalam pemahaman, menstimulus sasaran pelatihan untuk meneruskan yang diterima, dan mempermudah penerimaan informasi. Selain itu, sebagian besar pengetahuan manusia diperoleh dari mata dan telinga yang menumbulkan perubahan perilaku.

Penanaman kesadaran pentingnya pijat bayi adalah hal yang perlu dipahami oleh ibu terhadap bayinya, diharapkan agar perilaku ibu dalam memijat bayi secara mandiri dapat dilakukan rutin secara teratur. Sehingga dengan pijat bayi akan menghasilkan anak anak yang cerdas dan mencapai pertumbuhan dan perkembangan yang optimal (Maharani, 2009). Penanaman kesadaran ini dilakukan dengan pemberian pelatihan pijat bayi kepada ibu.

Dilihat dari selisih hasil pre test dan post test dalam penelitian ini juga tampak jelas bahwa proses belajar seorang ibu memerlukan adanya motivasi dan informasi yang jelas serta mudah dipahami. adanya informasi tentang pijat bayi yang berguna untuk ibu dan keluarga, akan menambah atau memperoleh tingkah laku baru bagi ibu dan keluarganya (Notoadmodjo, 2007).

Penelitian ini diperkuat oleh penelitian yang dilakukan Devi (2012), dengan hasil adanya pengaruh pendidikan kesehatan pijat bayi terhadap perilaku ibu dalam melakukan pijat bayi secara mandiri di posyandu Krikilan Ngaglik Sleman Yogyakarta. Selain itu juga diperkuat oleh Butsainatul (2015) pada hasil penelitiannya, yaitu adanya pengaruh pendidikan kesehatan tentang pijat bayi terhadap perilaku ibu dalam memijat bayi 
secara mandiri di kelurahan Girimargo Sragen.

Sasaran dan tujuan dari pelatihan pijat bayi ini adalah ibu dengan bayi usia $1-12$ bulan dengan harapan ibu-ibu dapat meningkatkan pemahaman tentang pentingnya melakukan pijat bayi secara mandiri, sehingga tidak lagi mengandalkan dukun bayi mengingat besarnya manfaat dari pijat bayi yang dilakukan ibu secara mandiri.dengan melakukan pijat bayi mandiri ibu akan lebih mengetahui perkembangan bayi secara optimal. Perilaku ibu melakukan pemijatan secara mandiri dan rutin adalah kegiatan yang menyenangkan dan dapat membuat berkomunikasi secara intens ibu dan bayi. Pemijatan yang lembut dapat dilakukan sambil memandang mata dan bersenandung kepada anaknya, hal tersebut dapat meningkatkan kontak batin serta perasaan kasih sayang yang dapat memperkuat ikatan emosi (bonding) ibu dan bayi, bahkan sampai anak tumbuh dewasa (Maharani, 2009).

\section{KESIMPULAN}

Berdasarkan analisis dan pembahasan dapat disimpulkan bahwa :

1. Sebelum dberikan pelatihan pijat bayi menunjukkan perilaku ibu pada kategori kurang

2. Setelah diberikan pelatihan pijat bayi perilaku ibu meningkat pada kategori cukup sebesar $65 \%$, baik $20 \%$ dan kurang $15 \%$

3. Ada pengaruh pelatihan pijat bayi terhadap perilaku ibu di Wilayah Kelurahan Plesungan Hal ini terbukti dengan hasil uji wilcoxon diperoleh hasil nilai $\mathrm{Z}-3.287^{\mathrm{a}}$ dan $\mathrm{p}$-value 0,000 menunjukkan hipotesis diterima. Terlihat jelas selisih kedua data pre-test dan post-test bermakna. Hal ini berarti dengan adanya pelatihan pijat bayi sangat membantu ibu dalam meningkatkan perilakunya dalam melakukan pemijatan bayi secara mandiri.

\section{SARAN}

Bagi responden penelitian ibu-ibu yang memiliki bayi dapat menerapkan pijat bayi mandiri secara rutin dan dapat menyebarluaskan hasil pelatihan yang telah diberikan dari peneliti.
DAFTAR PUSTAKA

Devi Rismundari .2012. Pengaruh Pendidikan Kesehatan Pijat Bayi Terhadap Peerilaku Ibu Dalam Melakukan Pijat Bayi Secara Mandiri di Posyandu Krikilan Ngaglik Sleman Yogyakarta. Naskah Publikasi. STIKes Aisyiyah Yogyakarta.

Mauliddina, A. 2011. Pengaruh Pendidikan

Kesehatan Pijat Bayi Terhadap Pengetahuan, Sikap dan Perilaku Meolaksanakan Pijat Bayi di Wilayah Puskesmas Mlati 1 Sleman. Skripsi tidak dipublikasikan. DIV Kebidanan. STIKES 'Aisyiyah Yogyakarta.

Notoatmodjo, S. 2010. Metodologi Penelitian Kesehatan (Edisi Revisi). Jakarta: Rineka Cipta. . 2007. Pengantar Pendidikan dan Ilmu Kesehatan. Yogyakarta: Offset. 2003. Pendidikan dan Perilaku Kesehatan. Jakarta : Rineka Cipta. 2011. Pendidikan dan Perilaku Kesehatan. Jakarta : Rineka Cipta.

Nursalam. 2008. Metodologi Penelitian Ilmu Keperawatan Pendekatan Praktis. Jakarta: Salemba Empat. 2013. Metodologi Penelitian Ilmu Keperawatan Pendekatan Praktis. Jakarta: Salemba Empat.

Maharani, S. 2009. Pijat \& Senam Sehat Untuk Bayi. Jakarta. Kata Hati

Roesli, U. 2010. Pedoman Pijat Bayi. Jakarta: PT. Trubus Agriwidya.

Subakti \& Rizky. 2008. Keajaiban Pijat Bayi dan Balita. Jakarta: Wahyu Media. 